DOI: $10.19195 / 0137-1150.163 .16$

\author{
FRANCISZEK APANOWICZ \\ Uniwersytet Gdański, Polska \\ frapan@wp.pl
}

\title{
Starość i stary człowiek w poezji Nikołaja Zabołockiego. Kilka spostrzeżeń
}

Zacznę od uściślenia tematu, który był zbyt ambitny, jak na krótki referat oraz — co tu ukrywać — jak na moje możliwości. Gdy formułowałem ten temat, nie zdawałem sobie sprawy z tego, jaką rozległą problematykę on otwiera. Myślałem nawet - pozwolę tu sobie na żart — co też na temat starości może wiedzieć taki młodzik. Zabołocki zmarł w wieku pięćdziesięciu pięciu i pół roku, co dziś oznacza drugą młodość, a i sześćdziesiąt lat temu nie było traktowane jako głęboka starość. Nie wiadomo jedynie, o ile lat postarzał go pobyt w łagrze. Jednakże czy mogę z pełnym przekonaniem powiedzieć, że - tylko z racji wieku - jestem ekspertem od problematyki starości? Własne doświadczenie powiedziało mi o rozmaitych dolegliwościach, które niesie ze sobą starość, typu coraz gorzej widzę, coraz gorzej słyszę, tu mnie strzyka, tu mnie boli. Coraz lepiej poznałem własne organy wewnętrzne - serce, wątrobę, nerki, trzustkę - cały atlas anatomiczny. Ale czy dowiedziałem się czegoś, czego nie wiedziałem wcześniej? Raczej nie. Owszem, poczułem to na własnej skórze. Poznałem również — podobno — pewne uroki pogodnej starości. I tutaj powiem — owszem. Lecz nadal nie widzę jakiejś większej mojej przewagi w wiedzy $\mathrm{i}$ - zwłaszcza - rozumieniu starości, będących prostą konsekwencją tych doświadczeń. Wreszcie rzecz moim zdaniem ostatnia, pewnie najważniejsza - sytuacja coraz silniej odczuwanej, coraz dotkliwszej świadomości zbliżania się śmierci. Taka wiedza byłaby z pewnością bardzo interesująca dla wszystkich, gdyby dało się ją przekazać innym bez zniekształceń. I znowu: czy istnieje tylko jeden model przeżywania tej sytuacji? Inaczej przeżywa ją prawdziwie i głęboko wierzący chrześcijanin — wiarą przenoszącą góry, a inaczej ktoś, kto tego daru jest pozbawiony. Pierwszy stoi przed bramą prawdziwego życia, nawet gdy czasem obejmuje go trwoga. Drugi raczej nie ma takich oczekiwań. Zupełnie inaczej też — ideologiczny wyznawca kultu 
młodości, jak futuryści lub, przynajmniej w pewnym okresie, władze bolszewickie. Poza tym istnieje jeszcze wiele innych wiar i modeli przeżywania tej sytuacji egzystencjalnej. Czyli zarówno sposób jej rozumienia, jak i przekazywania tego doświadczenia innym zależy od czynników zewnętrznych wobec samej tej sytuacji, leżących w postawie światopoglądowej dywagującego o starości. I nie wiem, czy brak dystansu jest tu pomocny. Może właśnie niezbędny jest dystans. W takim wypadku można całkiem zasadnie spodziewać się, że na temat starości wiele interesujących i do tego ważnych myśli mogą wypowiedzieć również ludzie młodzi, a nie wyłącznie starcy, zwłaszcza zaś tacy — żeby pozostać całkowicie konsekwentnym w tego rodzaju myśleniu — którzy stoją już nad grobem.

Dlatego niniejszy tekst traktuję nie jako nawet najbardziej wstępny zarys problematyki starości u Zabołockiego, zakładający jakąś próbę ogarnięcia całości, lecz jedynie jako garść mniej lub bardziej luźnych uwag na ten temat.

Największą liczbę wierszy o starości i starych ludziach napisał Zabołocki w ostatniej dekadzie swojego życia, jednak czasem poruszał ten temat także w utworach wcześniejszych, w których pełnił on rozmaite funkcje. Na przykład w powstałym w 1927 roku wierszu Новый был mamy o nich zaledwie kilka wzmianek, ale stanowią one tu człon zasadniczej opozycji zarysowanej z pozoru zgodnie z obowiązującą propagandą — jako stary i nowy świat. Utwór otwiera wizja rodzenia się nowego świata $\mathrm{w}$ celowo dobranych sztampowych obrazkach wschodzącego słońca i Nowego Życia pukającego do metaforycznych drzwi, a towarzyszą temu nie narodziny, jak można byłoby się spodziewać, ale zupełnie nieodpowiadające tej sytuacji chrzciny nowo narodzonego dziecka, co komplikuje nieco sztampę, aczkolwiek nadal mieści się w zarysowanej opozycji, gdyż wyostrza kontrast między starym i nowym światem poprzez zderzenie ze sobą aktów i aktantów przynależnych do obu tych rzeczywistości:

\footnotetext{
Восходит солнце над Москвой,

Старухи бегают с тоской:

Куда, куда идти теперь?

Уж Новый Быт стучится в дверь!

Младенец, выхолен и крупен,

Сидит в купели, как султан.

Прекрасный поп поет, как бубен,

Паникадилом осиян.

Прабабка свечку зажигает,

Младенец крепнет и мужает ${ }^{1}$.
}

Semantyka obrazów staruch jest jednoznacznie pejoratywna: zachowują się wbrew rozsądkowi - wschodzi słońce, zaczyna się nowy dzień, a one wpadają w panikę i nie wiedzą, gdzie się podziać. Powtórzone dwukrotnie pytanie „куда, куда" jest imitacją gdakania kur (кудахтанье) i tym samym upodabnia je do spłoszonych, rozbieganych, gdaczących, zgodnie ze stereotypem — głupich kur.

${ }^{1}$ Н. Заболоцкий, Собрание сочинений в трех томах, Москва 1983, t. 1, s. 42 (dalej ро cytatach $\mathrm{z}$ tej publikacji w nawiasach podano numer tomu i strony). 
Następujące po owym pytaniu-,,gdakaniu” słowa „Уж Новый Быт стучится в дверь!" stanowią proste wyjaśnienie, dlaczego wpadły w popłoch — boją się Nowego Życia, co oznacza, że należą do starego świata. Natomiast postać prababki nie ma cech wyraźnie pejoratywnych, ona po prostu zapala świecę, jak przystoi w takiej sytuacji prababce, zwłaszcza stojącej już nad grobem. Jednocześnie czyn ten przeciwstawiony został wzrostowi i mężnieniu nowo narodzonego, o czym mowa jest w tym samym zdaniu, co można uznać za kropkę nad $i$ w charakterystyce samej prababki. Z kolei ojciec bohatera, określony ciepłymi słowami „папенька-отец”, nie ma w ogóle cech negatywnych, on po prostu zaczął szybciej się starzeć, gdy syn wstąpił do komsomołu, a czas ruszył, jak z kopyta: „И время двинулось быстрее, / Стареет папенька-отец”. Oznacza to odchodzenie starego świata.

Do starego świata zalicza się zgodnie z obowiązującą propagandą również pop, który obdarzony został niezgodnymi ze stereotypem epitetami „прекрасный” i „кудрявый”, nieprzystającymi jednak do jego godności duchownego, co czyni tę postać dwuznaczną. Jego obraz deprecjonuje ponadto ironiczne określenie „паникадилом осиян”, z zasobów leksyki archaicznej i podniosłej, ale tu parodiujące aureolę. Pop pojawia się w wierszu dwukrotnie — na chrzcie i podczas wprowadzania się nowożeńców do nowego, dużego mieszkania (bez wątpienia jest to zamierzona kpina, wszystkim znane były kłopoty mieszkaniowe w tamtych latach, które tak błyskotliwie opisał Michaił Bułhakow). W drugiej odsłonie postać popa jest bardziej karykaturalna: podryguje nogami, w dłoniach chowa relikwie, chce pobłogosławić nie dom, mieszkanie, lecz ściany mieszkania (dokładniej - стенки), со odbiera sens całemu temu rytuałowi. W końcu młodzieniec, który przedstawił się jako wolontariusz Nowego Życia, przepędza popa, mówiąc, że czeka go już tylko grób. Wszystkie te postacie wyraźnie przypominają mieszkańców starego świata: staruszki, burżuja na skrzyżowaniu i (również!) popa podczas zamieci z Dwunastu Aleksandra Błoka. Jest to, jak mi się wydaje, nawiązanie celowe i oczywiście parodystyczne: u Błoka staruszka wprost porównana została do kury, w opisie popa zaś użyty został ten sam archaizm „сиять” — również w celach parodystycznych: „крестом сияло брюхо на народ”2.

Starość zatem nie jest tu tylko kwestią wieku, lecz również ideologii. Jednak to nie cała prawda. Wiersz ten, podobnie jak i inne utwory Zabołockiego tamtego okresu, jest swoistym rebusem, w którym istotne sensy są w sposób skomplikowany zaszyfrowane ${ }^{3}$. Owo Nowe Życie, preferowane w ramach ideologii, również ma postać karykaturalną. Jego istota bowiem to przysmaki i przyjemności

2 А. Блок, Избранное, Москва 1995, s. 367, 368.

${ }^{3}$ Zdaniem A.F. Awdiejewej już w połowie lat dwudziestych Zabołockiemu udało się stworzyć specjalną poetycką formę wiersza-rebusu (ребусная форма стиха), w którym „в сложных словесных конструкциях, состоящих из алогичных метафор, гипербол и гротеска, зашифрованы высокие философские мысли”. Рог. А.Ф. Авдеева, „Как мир меняется! И как я сам меняюсь!” Творческий путь Н.А. Заболочкого (1903-1958), http://prediger.ru/forum/index.php?showtopic=762 [dostęp: 15.04.2015]. 
odzwierciedlające ideały mieszczańskie, bezwzględnie odrzucane przez oficjalną ideologię sowiecką:

И Новый Быт, даруя милость,

В тарелке держит осетра.

Варенье, ложечкой носимо,

Шипит и падает в боржом $(1,44)$.

Wśród akcesoriów nowego świata, poza już wymienionymi oraz chałwą i żołnierskim winem, nota bene przyniesionymi przez przewodniczącego (председателя - centralną figurę nowej rzeczywistości), pojawia się zagadkowa baba wielkanocna, która przyjmuje czerwona przemowę: „И, принимая красный спич, / Сидит на столике кулич" - 1, 43). Rzecz w tym, że w wariancie pierwotnym był tu groteskowo-komiczny obraz siedzącego na stoliku Lenina („Сидит на столике Ильич”), ale pod naciskiem redakcji autor zamienił Ильича па кулич, pozostawiając wzmiankę o przyjmowaniu czerwonej przemowy, со zachowało cały komizm sytuacji i wcale nie osłabiło groteski ${ }^{4}$. Groteskowy jest również obraz nowego człowieka, który przeskakuje błyskawicznie — przez stół („шагая через стол”) — do komsomołu, żeni się i wprowadza do nowego mieszkania, gdzie urządza wesele, co stanowi komiczną mieszaninę elementów obowiązującej ideologii i odrzucanych oficjalnie ideałów mieszczańskich. Tutaj wręcz narzucają się analogie do opowiadań satyrycznych Michaiła Zoszczenki, znakomitej Pluskwy i Łaźni Władimira Majakowskiego czy groteskowych sztuk Nikołaja Erdmana Mandat i Samobójca, zawierających równie błyskotliwe demaskatorskie wizje rzeczywistości sowieckiej i parodię wszechobecnego języka propagandy.

W zupełnie inny sposób od omówionego wyżej potraktowana została postać starego człowieka w niewielkim poemacie Птицы, z 1933 roku. Nie ma tu mowy o przeciwstawianiu starego i nowego, starych i młodych, na odwrót, stary człowiek jest nauczycielem młodego, pod jego kierunkiem uczeń przeprowadza sekcję gołębia, aby poznać jego budowę. Staje się to okazją do wyłożenia pewnych tez dotyczących wyznawanej przez Zabołockiego filozofii przyrody. Utwór powstał na pograniczu dwóch etapów w ewolucji poglądów poety, dlatego widzimy w nim niektóre elementy pochodzące z okresu pierwszego, w którym przyroda była rozumiana jako więzienie i arena wzajemnego pożerania się wszystkich istot żywych, a także z okresu drugiego, kiedy przyroda pojmowana była jako organ łączący w sobie pierwiastek materialny i duchowy. Dlatego opis drobnych robaczków żyjących jeszcze, poruszających się, wijących, które za chwilę ptaki będą dziobać, rozszarpywać, kruszyć jako swój pokarm, sąsiaduje tu z opisem organów gołębia, tak podobnych do organów innych zwierząt, a nawet do dzieł ludzkich rąk i umysłu (porównanie piersi gołębia do kadłuba statku), co jest wyrazem jed-

${ }^{4}$ T. Бек, Бессмертье перспективы. Николай Заболочкий и его гены сегодня, [w:] Н. Заболоцкий, Не позволяй душе лениться, http://royallib.com/read/zabolotskiy_nikolay/ne_ pozvolyay_dushe_lenitsya_stihotvoreniya_i_poemi.html\#0 [dostęp: 8.05.2015]. 
ności życia oraz materii i myśli w całym Wszechświecie (1, 413 i 415). Z drugiej strony są tu również pewne elementy filozofii przyrody Zabołockiego, które będą dominować dopiero w okresie trzecim, mianowicie traktowanie przyrody jako kochającej matki ${ }^{5}$. Poemat kończy się obrazem wieczoru i cichego zachodu słońca, który nauczyciel wita jako jasny wieczór własnego życia, jako własną starość: „Привет тебе, ясный мой вечер, вечер жизни моей, старость моя!” $(1,416)$. Również śmierć traktuje on w sposób pozytywny - jako odpoczynek, a grób jako wieczne posłanie, nad którym krążą, swoją koleja, niejako na równych zasadach, jako równorzędne elementy kosmosu, obłoki, ptaki i planety. Ziemię z kolei wprost nazywa swoją matką, do której łona wkrótce powróci: „Земля моя, мать моя, лягу — скоро лягу и я в твои недра" $(1,417)$. Z podobnym ujęciem starości spotkamy się również w niektórych późnych wierszach poety.

W latach trzydziestych, aż do chwili aresztowania, temat starości nie pojawia się, jego miejsce zajmuje bardzo absorbująca poetę śmierć oraz nieśmiertelność, która w jego utworach przybiera różne formy. Na przykład w wierszu „Вчера, о смерти размышляя...” (1936) nieśmiertelna jest przyroda jako całość, a w niej „и трав вечерних пенье, и речь воды, и камня мертвый крик”, i człowiek jako myśl przyrody, jako jej rozum. Dlatego oprócz śpiewu wieczornych ziól, pogwarek wody i martwego krzyku kamienia słyszymy głos Puszkina wśród liści, śpiew ptaków Chlebnikowa nad wodą i widzimy zarysowujące się w kamieniu oblicze filozofa Grigorija Skoworody ${ }^{6}$ - najbardziej cenionych przez Zabołockiego twórców, symbolizujących tu ów rozum przyrody. Nieprzypadkowe tu jest, jak się wydaje, zestawienie głosu Puszkina z liśćmi (świat roślin), śpiewu ptaków Chlebnikowa z wodą (dwa żywioły, powietrze i woda, a zarazem dwa światy — środowisko, z którego wyłoniło się życie, oraz inne środowisko, do którego się wzniosło) i Skoworody - z kamieniem symbolizującym w tym zestawieniu najprawdopodobniej trwałość зыбкой myśli. Z kolei w wierszu Метаморфозы (1937) znakiem nieśmiertelności jest wieczna przemiana jednych form życia $\mathrm{w}$ inne. Podobne ujęcie tego tematu spotykamy również w powojennym wierszu pod zobowiązującym tytułem Testament (Завещ̧ание, 1947), w którym starość bohatera potraktowana została jako wygaśnięcie życia, podobne do zgaszenia świecy, co nie jest wszelako końcem wszystkiego, albowiem teraz dopiero rozpoczyna się droga niekończących się przemian („Когда на склоне лет иссякнет жизнь моя / И, погасив свечу, опять отправлюсь я / В необозримый мир туманных превращений” - 1,223) wiążących ze sobą pokolenia tak, że dzieło doskonalenia świata rozpoczęte przez jedno z nich może być dokończone w innym, dalekim pokoleniu: „Чтоб [...] ты, дальний мой потомок, / Доделал то, что я не довершил" $(1,224)$.

${ }^{5}$ Г. Филиппов, Заболоиякии, [w:] Русская литература XX века. Прозаики, поэты, драматурги: биобиблиографический словарь в 3 m., red. Н.Н. Скатов, Москва 2005, t. 2, https:// books.google.pl/books?id=loOvBTLmzlsC\&pg=PA8\&lpg=PA8\&dq [dostęp: 1.02.2015].

${ }^{6}$ И голос Пушкина был над листвою слышен, / И птицы Хлебникова пели у воды. / И встретил камень я. Был камень неподвижен, / И проступал в нем лик Сковороды $(1,181)$. 
Ze względu na ograniczoną ilość miejsca nie sposób omówić wszystkich utworów Zabołockiego traktujących o starości, dlatego zatrzymam się jeszcze na kilku, które, jak mi się wydaje, wnoszą coś nowego do tej tematyki. Dlatego pominę na przykład wiersz Слепой (1946), w którym temat starości skontaminowany jest z motywem człowieka ociemniałego, wysuniętym zresztą na pierwszy plan i niejako przyćmiewającym tamten. Nie sposób jednak nie zwrócić uwagi na zastosowany $\mathrm{w}$ utworze znaczący zabieg kompozycyjny: na początku wiersza smutna i gniewna pieśń niewidomego starca została zderzona z symbolami młodości (wokół niego „молодые шумят поколенья”, szaleje wiosna i wstaje w oślepiającym blasku dzień), na końcu wiersza zaś, z jednej strony, z wielkim cudem, jakim jest ziemia, a $\mathrm{z}$ drugiej — $\mathrm{z}$ nadchodzącą nocą oraz, inaczej niż w poemacie Птищ̧bl, obojętnie świecącymi gwiazdami na niebie, które na pozór w sprzeczności z ową obojętnością powtarzaja jego pieśń („Ночь подходит. Ночные светила, / Повторяя тебя, / Равнодушно сияют вдали" - 1, 194-195).

Radykalnie odmienne ujęcie starości odnajdujemy w wierszu Воспоминание (1952) z ostatniej dekady życia poety. Zabołocki miał już za sobą zarówno główne etapy ewolucji literackiej, jak i doświadczeń życiowych — od bezwzględnie, w sposób napastliwy krytykowanego pierwszego zbiorku wierszy Столбиьь (1929), poprzez kolejne wcielenia jego poetyckiej filozofii przyrody, fascynację filozofią kosmizmu rosyjskiego, a także znajomość z Konstantinem Ciołkowskim, próby ratowania się i peany na cześć reżimu w drugiej połowie lat trzydziestych, następnie aresztowanie, tortury i łagier oraz zsyłkę, po odzyskanie wolności i poświęcenie się głównie przekładom, w tym tłumaczeniu na język współczesny arcydzieła staroruskiego Stowo o wyprawie Igora. Swoim wierszem właściwie przerwał milczenie, które trwało kilka lat (1949-1952) i spowodowane było obawami, że nowe wiersze mogą dać władzom pretekst do kolejnego aresztowania, zwłaszcza że po wojnie przeprowadzano liczne masowe aresztowania fala za falą.

W wierszu dominuje tonacja bezpośredniego osobistego wyznania. Mimo iż ,ja” liryczne, podobnie jak w większości wcześniejszych jego utworów, nie jest ujawniane wprost, to bezpośrednio prezentowane są rozmyślania podmiotu wyraźnie utożsamiającego się z kimś starszym, kto dotkliwie odczuwa starzenie się i dolegliwości związane z tym procesem, takie jak trwająca miesiącami senność („Наступили месяцы дремоты” - 1,248) czy brak apetytu, wyrażony za pośrednictwem sugestywnej anafory:

Хочет пить - не нравятся ей вина,

Хочет есть - кусок не лезет в рот.

Wyliczenie tych starczych przypadłości przeplatane jest pytaniami egzystencjalnymi zadawanymi samemu sobie o to, czy objawy te oznaczają już zbliżanie się śmierci, czy życie rzeczywiście się kończy. Pytania te również wzmocnione zostały potężnym rytmem anafory, podobnie jak w przytoczonym wyżej dwuwierszu, dzięki czemu przedstawione warianty — życie przeminęło, po prostu, i życie zakończyło wszystkie swoje prace, a więc jest gotowe do odejścia i teraz 
tylko na chwilkę usiadło przy stole, niejako w przelocie, jak gość - stają się autentyczną alternatywą życia niespełnionego i spełnionego, przy czym ten drugi wariant, życia spełnionego, wydaje się bardziej przejmujący:

То ли жизнь, действительно, прошла,

То ль она, закончив все работы,

Поздней гостьей села у стола.

Jak się wydaje, właśnie to życie, późny gość, który usiadł na chwilę (podkreślmy, iż w języku rosyjskim życie jest rodzaju żeńskiego, a wyraz „gość” występuje w obu rodzajach, męskim i żeńskim - гостья), słucha szeptu jarzębiny i tego, jak śpiewa szczygieł za oknem. Dwie ostatnie strofy są natomiast relacją z tego, o czym śpiewa szczygieł, dzięki czemu nad całością wypowiedzi do końca panuje podmiot liryczny, który wciela się w rolę człowieka stojącego w obliczu śmierci i snującego rozważania o umieraniu, a następnie opowiadającego treść pieśni szczygła. Szczygieł w symbolice chrześcijańskiej od czasów św. Izydora z Sewilli jest wiązany z męką Chrystusa: według legendy wyjmował ciernie z korony wbite w jego głowę, gdy wisiał na krzyżu. Szeroko znane są obrazy Madonny ze szczygłem Rafaela oraz Madonny z Dzieciątkiem Carla Crivellego. Nie jest wykluczone, że Zabołocki, który był bardzo oczytany, zetknął się z tą symboliką szczygła, dlatego powierzył mu wstrząsającą opowieść o Syberii, dalekim kraju skutym śmiertelnym uściskiem mrozu. Symbolami tego kraju oraz wielkiej męki, jaka tam dotknęła ludzi i całą przyrodę, są zamieć, która zasypała krystalicznym śniegiem kopczyk samotnego grobu, skute lodem korzenie zamilkłej na zawsze brzozy i skrwawiony księżyc na niebie, ściśnięty obręczą mrozu. Obraz ten jest poetycką reminiscencją wspomnień z łagrów, został jednak celowo odrealniony, nie pokazuje tysięcy więźniów, ich morderczej pracy i ich masowego umierania, lecz tylko jeden grób zasypany śniegiem, tylko jedną umierającą brzozę, tylko jeden, chciałoby się powiedzieć, skrwawiony księżyc płynący nad martwym krajobrazem, dzięki czemu stają się potężnym, wstrząsającym symbolem wszechogarniającego uniwersum śmierci. W wygłosie wiersza ponownie została użyta anafora - by jeszcze bardziej wzmocnić oddziaływanie całego obrazu. Wyraz „anafora” pochodzi z języka greckiego, w którym oznacza podniesienie — i taką funkcję pełni w utworze Zabołockiego. Nie przypadkiem stała się kluczową figurą retoryczną w wierszu, w którym wystąpiła aż trzykrotnie, osiągając w końcówce najwyższą siłę oddziaływania ${ }^{7}$. W wyniku tych zabiegów zarysowana na wstępie sytuacja niejako ulega odwróceniu: śmierć w swoim najstraszliwszym wymiarze tak naprawdę została $\mathrm{w}$ dalekiej przeszłości i w zestawieniu z nią śmierć, która czeka bohatera, nie ma tej grozy.

Z kolei w wierszu Где-то в поле возле Магадана... (1956) nie mamy już do czynienia ze wspomnieniem o Syberii i łagrze, lecz z epizodem bezpośrednio rozgrywającym się w przestrzeni łagrów syberyjskich: dwaj starsi więźniowie („Два несчастных русских старика”) wysłani bez konwoju po mąkę idą zgar-

${ }^{7}$ Zabołocki bardzo często sięga do anafory w swoich wierszach. 
bieni, zmęczeni przez bezkresną mroźną pustynię. Narracja utrzymana jest w poetyce realistycznej, ale świat przedstawiony wyraźnie rozpada się na dwie części czy raczej na dwa poziomy: górę i dół, niebo i ziemię, pomiędzy którymi nie ma łączności - na niebie świecą gwiazdy, symbole wolności (символы свободы), stanowiące kontrast do niewoli więźniów, ale nie patrzą na nich, podobnie nie dociera do nich wspaniałe misterium zorzy polarnej. Staruszkowie mają własne wielkie zmartwienia: wrzaski konwoju, kryminaliści, tęsknota za domem i bliskimi, zmęczenie, w tym zmęczenie życiem, całkowite wypalenie dusz (,вся душа у них перегорела") i nie dostrzegają życia, które toczy się wysoko nad nimi: „Жизнь над ними в образах природы / Чередою двигалась своей”. W ogóle nie interesuje ich życie, także własne, siadają na pniu i zamarzają. I wtedy stają się naprawdę wolni i od strażników, i od konwoju, tylko gwiazdy stają nad nimi jak na warcie honorowej:

Не нагонит больше их охрана,

Не настигнет лагерный конвой,

Лишь одни созвездья Магадана

Засверкают, став над головой $(1,279)$.

Całkiem pozbawiony grozy, można by rzec wręcz idylliczny wizerunek starości został przedstawiony w wierszu zatytułowanym właśnie Starość, powstałym w 1956 roku, kiedy poeta miał już pięćdziesiąt trzy lata i zapewne uważał się za człowieka w podeszłym wieku. W nieco wcześniejszym wierszu Sen, z 1953 roku, kiedy Zabołocki miał równo pięćdziesiąt lat, ten właśnie wiek potraktowany został umownie jako granica życia. Idylliczny charakter nadaje wizerunkowi starości wprowadzenie pary bohaterów, nobliwych staruszków, którzy spacerują wśród jesiennych drzew. Znakiem jesieni współgrającej z wiekiem staruszków są листья золотые. Złoto nadaje rys szlachetności i jesieni, i podeszłemu wiekowi, bo przecież liście mogły być na przykład pożółkłe, co podkreślałoby niszczący upływ czasu, albo nawet zwyczajnie żółte, co byłoby emocjonalnie neutralne. Idylliczny charakter podkreślają również akcesoria — laseczka i parasolka („ОH с палкой, с зонтиком она" - 1, 287), a także epitety określające staruszków - простые, тихие, седые. Pierwsza strofa, z ich portretem, zostaje powtórzona dosłownie w końcówce wiersza, choć z dodaniem pointy lirycznej, zamykającej cały utwór, ale nieniweczącej funkcji powstałej w wyniku powtórzenia ramy, przeciwnie, nawet wzmacniającej semantykę powtórzonego portretu.

Wydźwięk idylliczny wiersza wzmaga też informacja o bezpośrednim porozumieniu dusz niepotrzebujących słów, a także o ich zwykłym szarym życiu naznaczonym cierpieniami oraz o dolegliwościach ich starczego wieku, o tym, że są przygnieceni niemocą i opadają z sił, ale te dolegliwości łagodzi, a może znosi nierozerwalna, wieczna jedność ich dusz, przy czym autor nie obawia się patosu i nie unika wielkich słów, które w tym kontekście brzmią jednak naturalnie, nie rażą, przeciwnie, mogą budzić u czytelnika empatię, a nawet rozczulenie: 
Изнемогая, как калеки,

Под гнетом слабостей своих,

В одно единое навеки

Слились живые души их.

Owa nierozerwalna wieczna jedność obojga staruszków jest znakiem wielkiej miłości, chociaż nie zostało to powiedziane wprost, tylko finezyjnie zasugerowane, podobnie jak niejawne, lecz bardzo wyraźne reminiscencje starożytnego greckiego mitu o miłości Filemona i Baucis. Rozwinięta natomiast została inna myśl o szczególnej wiedzy, jaką zawdzięczają swojemu podeszłemu wiekowi, czyli wieloletniemu doświadczeniu życiowemu — że szczęście w życiu człowieka jest nieuchwytne, niczym mgnienie, daleki błysk („счастье наше - лишь зарница"), który znika tuż po pojawieniu się i nic nie jest w stanie go zatrzymać, może nawet miłość. Ta myśl nie tylko została wyrażona w sposób dyskursywny, za pośrednictwem słów, lecz również odegrana, niczym w teatrze, za pomocą śmiałych obrazów metaforycznych, porównań, antropomorfizacji, anafor:

Как ни лелей его в ладонях,

И как к груди ни прижимай, -

Дитя зари, на светлых конях

Оно умчится в дальний край.

Pointa liryczna sformułowana w ostatniej strofie jest bezpośrednim nawiązaniem do portretu pary bohaterów z pierwszej strofy wiersza, powtórzonego następnie w strofie przedostatniej, a poprzez nią — i do myśli o nieuchwytnym szczęściu, za którego mirażem już nie gonią i pewnie dlatego są bezpieczni, bez strachów, które osaczały ich dawniej. Ich złączone na wieki dusze porównane zostały do spokojnie dopalających się świec, które ciągle wydzielają jeszcze słabiutkie strużki ciepła. Skonstruowany tu został obraz starości pogodnej oraz umierania bezbolesnego, wręcz błogiego, jednoznacznie kojarzącego się z zasłużonym odpoczynkiem po spełnionym życiu:

Теперь уж им, наверно, легче,

Теперь все страшное ушло,

И только души их, как свечи,

Струят последнее тепло $(1,288)$.

Warto zwrócić uwagę na porównanie staruszków w końcówce wiersza do świec, niewyszukane zresztą i nierzadko stosowane zarówno w literaturze pięknej, jak i w wypowiedziach potocznych, obecne również $\mathrm{w}$ innych wierszach Zabołockiego. Świece stosowane są w cerkwi jako symbol modlitwy wiernych, mogą więc także w wierszu Zabołockiego oznaczać cichą przedśmiertną modlitwę. Jednak podkreślenie w poincie lirycznej, że dusze ich sączą ostatnie resztki ciepła, symbolizują raczej ledwo tlące się, ale obecne aż do śmierci uczucie taką spokojną, wyzbytą z młodzieńczej namiętności starczą miłość. Właściwie to oba znaczenia tlących się świec korespondują ze starożytnym mitem, co zapewne zamierzone jest przez autora. 


\section{Bibliografia}

Авдеева А.Ф., ,ККакмир меняется! И как я сам меняюсь!” Творческий путь Н.А. Заболоикого (1903-1958), http://prediger.ru/forum/index.php?showtopic=762.

Бек Т., Бессмертье перспективы. Николай Заболоикий и его гены сегодня, [w:] Н. Заболоцкий, Не позволяй душе лениться, http://royallib.com/read/zabolotskiy_nikolay/ne_pozvolyay_ dushe_lenitsya_stihotvoreniya_i_poemi.html\#0.

Блок А., Избранное, Москва 1995.

Заболоцкий Н., Собрание сочинений в трех томах, t. 1, Москва 1983.

Русская литература XX века. Прозаики, поэты, драматурги: биобиблиографический словарь в 3 m., t. 2, red. Н.Н. Скатов, Москва 2005.

\section{Old age and an old man in the poetry of Nikolay Zabolotsky. A few remarks}

\section{Summary}

This article analyses the theme of the old age in the poetry of Nikolay Zabolotsky. A few poems from different periods of the poet's artistic life are being considered. These poems show the theme of old age in the most complete way. In the poem New Life the old age was incorporated into an ideological opposition ,an old and new world" but both these elements became the subject of a parody. The poems Birds and „Yesterday, while thinking about death..." show an idea of the poet's nature philosophy. In the first poem the old age and youth unite in the mutual cognitive act. The second one talks about the unity of the nature where a man as the nature's brain has been perfecting it for generations. In the poem $A$ blind man this optimistic tone collapses. The sad song of a blind old man corresponds with the poet's feeling of being lost and with far light of the stars indifferent to humans. Recollection, however, is a meticulous combination of the description of old age afflictions and a symbolic vision of the icebound Siberia, while the poem ,Somewhere in the fields, nearby Magadan..." is a realistic description of wandering of old prisoners across the snowy wasteland of Siberia and their freezing to death somehow connected with the light spectacle of the stars in the night sky, stars indifferent to the fate of men. Old age is a lyrical reference to the ancient myth of Filemon and Baucis, which describes a calm death of the old couple united by the eternal love, and it is a sign of acceptance of death as an inseparable part of life.

Keywords: old age, life, death, immortality, nature philosophy, Russian cosmism

\section{Старость и старый человек в поэзии Николая Заболоцкого. Несколько замечаний}

\section{Резюме}

В статье рассматривается тема старости в поэзии Николая Заболоцкого. Анализу подверглось несколько стихотворений из разных периодов его творчества, в которых эта тема проявилась наиболее полным образом. В стихотворении Новый Быт старость включена 
в идеологическую оппозиционную пару „старый и новый мир”, но оба члена этой пары стали объектом пародии. Поэма Птииы и стихотворение Вчера, о смерти размылляя... выражают идеи его натурфилософии: в первом старость и молодость соединяются в совместном акте познания мира, а во втором речь идет о единстве всей природы, в которой человек, как ее разум, из поколения в поколение трудится над ее усовершенствованием. В стихотворении Слепой рушится этот оптимистический тон - грустная и злая песня слепого старика созвучна растерянности поэта и равнодушным по отношению к людям небесным светилам. Воспоминание - это искусное соединение описания старческих недугов с символической картиной скованной морозом сибирской равнины, а стихотворение Где-то в поле, возле Магадана... реалистическое описание идущих по снежной пустыне Сибири узников и их замерзания соединяет с мистерией небесных звезд, тоже равнодушных к судьбе людей. Старость является лирической реминисценцией древнего мифа о Филемоне и Бавкиде и описывает спокойную смерть соединенной вечной любовью пары старичков, что выражает примирение со смертью как неотъемлемой частью жизни.

Ключевые слова: старость, жизнь, смерть, бессмертие, натурфилософия, русский космизм

Slavica Wratislaviensia 163, 2016

(C) for this edition by CNS 